\title{
HUBUNGAN SANITASI LINGKUNGAN, POLA MAKAN DAN PERSONAL HYGIENE DENGAN KEJADIAN TYPHOID PADA PASIEN YANG DI RAWAT DI BLUD RSU TENRIA WARU KABABUPATEN BONE
}

\section{Relationship of Environmental Sanitation, Diet and Personal Hygiene with The Incidence of Typhoid in Patients Treated in Blud RSU Tenriawaru District Bone}

\author{
Fitrah Ramadani \\ Akper Lapatau Bone
}

\section{Riwayat artikel}

Diajukan: 26 Agustus 2019

Diterima: 19 September

2020

\section{Penulis Korespondensi:}

- Fitrah Ramadani

- Akper Lapatau Bone

Fitrahramadani16@gmail.c om

\section{Kata Kunci:}

typhoid, sanitasi lingkungan, pola makan dan personal hygiene
Abstrak

Pendahuluan: Penyakit typhus abdominallis atau demam thypoid merupakan problem atau masalah yang serius bagi kesehatan masyarakat. Hal ini disebabkan masih kurangnya kesadaran tentang penyebab dan bahaya penyakit typhoid. Tujuan: Penelitian ini bertujuan untuk mengetahui adanya interaksi hubungan antara sanitasi lingkungan, pola makan dan personal hygiene dengan peristiwa kejadian typhoid. Metode: Jenis penelitianini bersifat penelitian deskriptif analitik dan menggunakan pendekatan "Cross Sectional Study" dengan jumlah sampel 42 responden dengan tehnik probability sampling.Analisa data menggunakan SPSS, dengan uji fisher's exact test). Hasil: Berdasarkan hasil uji statistik hubungan sanitasi lingkungan $p=0,021$ hubungan pola makna $p=0,019$ dan hubungan personal hygiene $p=0,020$ terhadap kejadian typhoid. Pembahasan: Sehingga dapat menarik kesimpulan bahwa ada hubungan antar variabel. Berdasarkan dari hasil penelitian maka disarankan pasien yang menderita penyakit typhoid, agar senantiasa menjaga dan memelihara sanitasi lingkungan, pola makan dan personal hygienenya. Bagi peneliti selanjutnya perlu melakukan penelitian dengan memaikai metode lain dan mengambil sampel yang lebih banyak supaya output penelitian lebih objektif.

\begin{abstract}
Background: Typhus abdominalis or typhoid fever is a serius problem for publicc health. This is due to the lack of awareness about the causes and dangers of typhoid disease. This study aims to determine the relationship of environmental sanitation, diet and personal hygiene with typhoid events. Method: This type of research is analytic descriptive research and uses the approach of "Cross Sectional Study" with a sample of 42 respondents. Data analysis using questionnaire sheets and SPSS, with fisher's exact test. Results: Based on the results of statistical tests of the relationship of environmental sanitation $p=0.021$ relationship between eating patterns $p=0.019$ and the relationship of personal hygiene $p=0.020$ on the incidence of typhoid. Discussion: So it can be concluded that there is a relationship between variables. Based on the results of the study it is recommended that patients suffering from typhoid disease, to always maintain and maintain environmental sanitation, diet and personal hygiene. For further researchers need to conduct research using other methods and using more samples so that research results can be more objective.
\end{abstract}




\section{PENDAHULUAN}

Typhus Abdominalis masih ada di seluruh global dan penyebarannya tidak tergantung pada iklim, Namun lebih banyak di temukan di negara-negara berkembang di daerah tropis. Diare dan Typhoid abdominalis (demam typhoid, entric fever) merupakan penyakit infeksi akut yang umumnya mengenai saluran pencernaan dengan gejala demam yang lebih dari satu minggu, gangguan pada pencernaan dan gangguan kesadaran, penyebab penyakit ini adalah Salmonela Thyphosa (Ardiansyah Muhammad, 2012)

Menurut (Harjo, 2010) Penyakit typhus abdominallis atau demam typhoid adalah masalah yang serius untuk kesehatan masyarakat di negara-negara yang berkembang seperti Indonesia yang memiliki iklim tropis beberapa di temukan penyakit infeksi diantaranya adalah Typhus Abdominalis yang di temukan sepanjang tahun. Typhus abdominalis di sebabkan oleh virus salmonella typhi. Jika virus salmonella tyhpi masuk bersama makanan atau terkontaminasi, aka virus akan bersarang dijaringan limfoid pada dinding usus. Aliran limfe membawa organ ini kedalam hati dan empedu. Gejala demam typhoid atau Typhus abdominalis yaitu suhu tubuh meningkat hingga $40^{\circ} \mathrm{C}$ dan frekuensi nadi menjadi lambat. Gejala lain yang sering muncul adalah nyeri tekan dibagian abdomen (Ardiansyah Muhammad, 2012).

Data Badan Kesehatan Dunia (WHO) menemukan jumlah kasus demam typhoid di seluruh belahan dunia hingga mencapai 16-33 juta penderita, dengan 500.000 sampai 600.000 kematian setiap tahun. Negara yang paling tinggi terkena demam typhoid yaitu negara di kawasan Asia Tengah (Pakistan, Bangladesh, India) dan Asia Tenggara (Indonesia dan Vietnam).

Di negara-negara berkembang diprediksi angka kejadian demam typhoid bervariasi dari 10 sampai 540 per 100.000 penduduk. Meskipun angka kejadian demam typhoid mengalami penurunan dengan adanya sanitasi pembuangan di berbagai negara berkembang, diprediksikan setiap tahunnya masih terdapat 35 juta kasus dengan 500.000 kematian terdapat di dunia. Di Indonesia demam typhoid masih merupakan penyakit endemik dengan angka kejadian yang masih tergolong tinggi. Di antara penyakit yang termasuk penyakit infeksi usus, demam typhoid menduduki urutan kedua setelah gastroenteritis.

Di Indonesia, diperkirakan kejadian demam enterik yaitu 300-810 kasus per 100.000 penduduk per tahun. Menurut hasil SKRT bahwa $3 \%$ dari seluruh kematian yaitu (50.000 kematian) disebabkan oleh demam enterik. Penyakit ini meskipun sudah dinyatakan sembuh, namun penderita belum dikatakan sembuh hal ini desebabkan karena mereka masih dapat menularkan penyakitnya kepada orang lain (bersifat carrier). Kemungkinan perempuan untuk menjadi carrier 3 kali lebih tinggi dibandingkan pada laki-laki. Sumber penularan utama adalah penderita demam enterik itu sendiri dan carrier, dimana mereka dapat mengeluarkan berjuta-juta kuman Salmonella typhi dalam bentuk tinja dan tinja inilah yang menjadi sumber pencemaran (saidam Gouzali, 2011).

Penyakit Typhus (demam typhoid) di Provinsi Sulawesi Selatan (SUL-SEL) pada tahun 2005 terdapat 16.478 kasus, dengan angka kematian sebanyak 6 orang $(\mathrm{CFR}=1 \%)$. Berdasarkan informasi yang di terima oleh Subdin P2\&PL Dinkes Provinsi Sulawesi selatan (SUL-SEL) dari beberapa Kabupaten yang menjadi kasus tertinggi yaitu Kota Parepare, Kota Makassar, Kota Palopo, Kabupaten Enrekang dan Kabupaten Gowa. Dan untuk tahun 2006, tercatat jumlah penderita sebanyak 16.909 dengan angka kematian sebanyak 11 orang $(\mathrm{CFR}=0,07 \%)$ dan sebaran kasus tertinggi di Kabupaten Gowa, Kota Makassar, Kota Parepare dan Kabupaten Enrekang.

Pada tahun 2009 tercatat jumlah penderita yaitua sebanyak 16.552 dengan angka kematian sebanyak 5 orang $(\mathrm{CFR}=0,03 \%)$ dengan sebaran kasus tertinggi di Kabupaten Gowa, Kabupaten Enrekang dan Kota Makassar. Penyakit typhoid berdasarkan Riskesdas tahun 2009 secara nasional di Sulawesi Selatan, penyakit typhoid tersebar di semua umur sedangkan yang cenderung lebih tinggi adalah pada umur dewasa. Prevalensi klinis banyak ditemukan terhadap kelompok umur sekolah ialah $1,9 \%$, terendah pada bayi ialah $0,8 \%$. (Riskesdas, 2009). 
Dari data program tahun 2008 penyakit typhoid tercatat terdapat penderita berkisar sebanyak 20.088 dengan angka kematian sebanyak 3 orang, masing-masing Kabupaten Gowa (1 orang) dan Kabupaten Barru (2 orang) atau $\mathrm{CFR}=0,01 \%$. Insiden Rate (IR=0.28\%) yaitu tertinggi di Kabupaten Gowa yaitu 2.391 kasus dan yang terendah di Kabupaten Luwu yaitu 94 kasus, tertinggi pada umur 15-44 tahun) sebanyak 15.212 kasus (Harjo, 2010). Hasil rekapitulasi medical di BLUD RSU Tenriawaru Kabupaten Bone, dimana pasien typhoid yang dirawat di BLUD RSU Tenriawaru Kabupaten Bone mulai tahun 2011 - 2012 sebanyak 607 orang.

Berdasarkan prevalensi data kasus penyakit typhoid tersebut, dengan ini mendorong peneliti untuk mengetahui lebih lanjut dan menelusuri berbagai penyebab, memperdalam pemahaman mengenai hubungan sanitasi lingkungan, pola makan dan personal hygiene dengan kejadian typhoid di BLUD RSU Tenriawaru Kabupaten Bone.

\section{METODE}

Jenis dan metode penelitian yang digunakan adalah Deskriptif Analitik dengan pendekatan Cross Sectional Study.Cross Sectional Study adalah suatu penelitian untuk mempelajari dinamika korelasi antara faktorfaktor resiko dengan efek, dengan cara pendekatan, observasi atau pengumpulan data sekaligus pada suatu saat (point time approach) artinya tiap subjek penelitian hanya diobservasi sekali saja dan pengukuran dilakukan terhadap status karakter atau variabel subjek pada saat pemeriksaan (Hariwijaya and Djaelani, 2011) Penelitian ini dilaksanakan di BLUD RSU Tenriawaru Kab.Bone dan dilakukan pada tanggal 20 juni s.d 18 juli 2013. Jumlah populasinya adalah 607. Besar sampel dalam penelitian ini sebanyak 42 dengan tehnik pengambilan sampel probability sampling, pasien typhoid yang dirawat di BLUD RSU Tenriawaru Kab.Bone selama 1 bulan berlangsungnya penelitian.

\section{HASIL DAN PEMBAHASAN HASIL}

Penelitian ini mengenai hubungan sanitasi lingkungan, pola makan dan personal hygiene dengan kejadian typhoid di BLUD RSU Tenriawaru Kabupaten Bone dilaksanakan selama 29 hari mulai dari tanggal 20 juni s.d 18 Juli 2013. Data dikumpulkan melalui kuesioner yang diberikan kepada pasien yang menderita penyakit typhoid di ruang interna RSU Tenriawaru Kabupaten Bone

Sampel penelitian secara keseluruhan yang diperoleh saat penelitian dilaksanakan sebanyak 42 responden dengan teknik accidental sampling. Responden pada penelitian ini mengenai seluruh penderita typhoid di ruang interna di BLUD RSU Tenriawaru Kabupaten Bone. Peneliti memberikan kuesioner kepada sampel yang ditemui pada saat penelitian.

Setelah pengambilan data dilakukan, langkah selanjutnya yaitu pengolahan dan analisis data untuk memperoleh hasil dari penelitian. Pengolahan data menggunakan program SPSS versi 16,0. Selanjutnya hasil penelitian secara lengkap dan terperinci disajikan dalam bentuk tabel distribusi frekuensi antara lain karakteristik demografi dan masing-masing variabel yang diteliti untuk mengetahui hubungan variabel independen terhadap variabel dependen, dimana menggunakan uji statistic fisher's Exact Test.

\section{Karakteristik Demografi Responden berdasarkan kelompok umur}

Tabel. 1 Karakteristik responden berdasarkan umur di BLUD RSU Tenriawaru Kab. Bone

\begin{tabular}{cccc}
\hline No & $\begin{array}{c}\text { Kelompok } \\
\text { umur }\end{array}$ & Frekuensi & $\begin{array}{c}\text { Presentasi } \\
(\%)\end{array}$ \\
\hline 1. & $15-20$ & 3 & 7.1 \\
2. & $21-30$ & 21 & 50.0 \\
3. & $31-50$ & 12 & 28.6 \\
4. & $>51$ & 6 & 14.3 \\
\hline & Total & 42 & 100 \\
\hline
\end{tabular}

Sumber: Data Primer, 2013

Berdasarkan Tabel 1. dapat diketahui bahwa jumlah responden yang berumur 15-20 tahun sebanyak 3 orang $(7,1 \%)$, umur 21-30 tahun sebanyak 21 orang $(50,0 \%)$, umur 31-50 tahun sebanyak 12 orang $(28,6 \%)$, umur $>51$ tahun sebanyak 6 orang $(14,3 \%)$. 
Karakteristik responden berdasarkan jenis kelamin

Tabel 2 Karakteristik responden berdasarkan jenis kelamin di BLUD RSU Tenriawaru Kab. Bone

\begin{tabular}{cccc}
\hline No & Jenis kelamin & Frekuensi & $\begin{array}{c}\text { Persentase } \\
(\boldsymbol{\%})\end{array}$ \\
\hline 1. & Laki-laki & 19 & 45,2 \\
2. & Perempuan & 25 & 54,8 \\
\hline & Total & $\mathbf{4 2}$ & $\mathbf{1 0 0}$ \\
\hline
\end{tabular}

Sumber: Data Primer, 2013

Berdasarkan Tabel 2 maka diketahui Jumlah responden laki-laki sebanyak 19 orang $(45,2 \%)$, sedangkan jumlah responden perempuan terdapat 25 orang $(54,8 \%)$.

\section{Karakteristik responden berdasarkan} pendidikan terakhir

Tabel 3 Karakteristik responden berdasarkan pendidikan terakhir di BLUD RSU Tenriawaru Kab. Bone

\begin{tabular}{cccc}
\hline No & $\begin{array}{c}\text { Pendidikan } \\
\text { terahir }\end{array}$ & Frekuensi & $\begin{array}{c}\text { Persentase } \\
(\boldsymbol{\%})\end{array}$ \\
\hline 1. & SD & 21 & 50,0 \\
2 & SMP & 15 & 35,7 \\
3 & SMA & 6 & 14,3 \\
\hline & Total & $\mathbf{4 2}$ & $\mathbf{1 0 0 , 0}$ \\
\hline
\end{tabular}

Sumber: Data Primer, 2013

Dan dari Tabel 3 diketahui bahwa jumlah responden yang memiliki tingkat pendidikan SD sebanyak 21 orang $(50,0 \%)$, tingkat pendidikan SMP sebanyak 15 orang $(35,7 \%)$, dan tingkat pendidikan SMA sebanyak 6 orang $(14,3 \%)$.

\section{Karakteristik responden berdasarkan pekerjaan}

Tabel 4 Distribusi responden berdasarkan pekerjaan di BLUD RSU Tenriawaru Kab. Bone

\begin{tabular}{cccc}
\hline No & Pekerjaan & frekuensi & $\begin{array}{c}\text { Persentase } \\
(\%)\end{array}$ \\
\hline 1 & PNS & 4 & 9,5 \\
2 & Wiraswasta & 10 & 23,8 \\
3 & Pelajar & 18 & 42,9 \\
4 & Petani & 10 & 23,8 \\
\hline & Total & 42 & 100,0 \\
\hline
\end{tabular}

Sumber: Data Primer, 2013

Dari Tabel 4 dapat diketahui bahwa responden yang memiliki pekerjaan sebagai
PNS sebanyak 4 orang $(9,5 \%)$, wiraswasta sebanyak 10 orang $(23,8 \%)$, pelajar sebanyak 18 orang $(42,9 \%)$ dan petani sebanyak 10 orang $(23,8 \%)$.

\section{Distribusi responden berdasarkan sanitasi lingkungan}

Tabel 5 Distribusi responden berdasarkan sanitasi lingkungan di BLUD RSU TenriawaruKab. Bone

\begin{tabular}{ccc}
\hline $\begin{array}{c}\text { Sanitasi } \\
\text { lingkungan }\end{array}$ & Frekuensi & $\begin{array}{c}\text { Persentase } \\
(\%)\end{array}$ \\
\hline Kurang baik & 31 & 73,8 \\
Baik & 11 & 26,2 \\
\hline Total & 42 & 100 \\
\hline
\end{tabular}

Sumber: Data Primer, 2013

Dari Tabel 5 diketahui bahwa responden yang memiliki sanitasi lingkungan yang kurang baik 31 orang $(73,8 \%)$ dan responden yang memiliki sanitasi lingkungan baik 11 orang $(26,2 \%)$.

\section{Distribusi responden berdasarkan pola} makan

Tabel 6 Distribusi responden berdasarkan pola makan di BLUD RSU Tenriawaru Kab. Bone

\begin{tabular}{|c|c|c|}
\hline Pola makan & frekuensi & $\begin{array}{l}\text { Persentase } \\
(\%)\end{array}$ \\
\hline Kurang & 30 & 71,4 \\
\hline baik & 12 & 28,6 \\
\hline Baik & & \\
\hline Total & 42 & 100 \\
\hline
\end{tabular}

Berdasarkan Tabel 6 dapat diketahui bahwa sebagian besar responden memiliki pola makan yang kurang baik sebanyak 30 orang $(71,4 \%)$ sedangkan yang memiliki pola makan yang baik hanya 12 orang $(28,6 \%)$.

\section{Distribusi responden berdasarkan personal} hygiene

Tabel 7 Distribusi responden berdasarkan personal hygiene di BLUD RSU Tenriawaru Kab. Bone

\begin{tabular}{ccc}
\hline $\begin{array}{c}\text { Personal } \\
\text { hygiene }\end{array}$ & frekuensi & $\begin{array}{c}\text { Persentase } \\
(\%)\end{array}$ \\
\hline Kurang baik & 34 & 81,0 \\
Baik & 8 & 19,0 \\
\hline Total & 42 & 100 \\
\hline Sumber: Data Primer, 2013 &
\end{tabular}


Berdasarkan tabel 7 diketahui bahwa sebagian besar responden memiliki personal hygiene yang kurang baik yakni 34 orang $(81,0 \%)$ sedangkan yang memiliki personal hygiene baik hanya 8 orang $(19,0 \%)$.

\section{Distribusi responden berdasarkan kejadian thypoid}

Tabel 8 Distribusi responden berdasarkan kejadian typhoid di BLUD RSU Tenriawaru Kab. Bone

\begin{tabular}{|c|c|c|}
\hline $\begin{array}{c}\text { Kejadian } \\
\text { typhoid }\end{array}$ & Frekuensi & Persentase (\%) \\
\hline Berat & 31 & 73,8 \\
\hline Ringan & 11 & 26,2 \\
\hline Total & 42 & 100 \\
\hline
\end{tabular}

\section{Analisa Bivariat}

\section{Hubungan sanitasi lingkungan dengan kejadian typhoid}

Tabel 9 Hubungan sanitasi lingkungan dengan kejadian typhoid di BLUD RSU Tenriawaru Kab. Bone

\begin{tabular}{lccccccc}
\hline Sanitasi & \multicolumn{4}{c}{ Kejadian typhoid } & \multicolumn{2}{c}{ Total } & $P$ \\
\cline { 2 - 9 } lingkungan & berat & $\%$ & ringan & $\%$ & $\sum$ & $\%$ & \multirow{2}{*}{0,02} \\
\hline Kurang baik & 26 & 61,9 & 5 & 11,9 & 31 & 73,8 & 1 \\
\hline Baik & 5 & 11,9 & 6 & 14,3 & 11 & 26,2 & 1 \\
\hline
\end{tabular}

Sumber: Data Primer, 2013

Berdasarkan Tabel 9, maka diketahui bahwa dari total 31 responden $(73,8 \%)$ memiliki sanitasi lingkungan yang kurang baik, 26 responden $(61,9 \%)$ diantaranya menderita typhoid berat dan 5 responden lainnya $(11,9 \%)$ menderita typhoid ringan. Sedangkan dari total 11 responden $(26,2 \%)$ yang memiliki sanitasi lingkungan yang baik, 5 responden $(11,9 \%)$ diantaranya menderita typhoid berat dan 6 responden $(14,3 \%)$ menderita typhoid ringan.

Hasil uji statistik fisher exact test antara variabel sanitasi lingkungan dengan kejadian typhoid diperoleh $p=0,021$ yang artinya ada hubungan yang signifikan antara sanitasi lingkungan dengan kejadian typhoid.

Hubungan antara pola makan dengan kejadian typhoid

Tabel 10 Hubungan pola akandengan kejadian typhoid di BLUD RSU Tenriawaru Kab.Bone

\begin{tabular}{llllllll}
\hline \multirow{2}{*}{ Pola makan } & \multicolumn{3}{l}{ Kejadian typhoid } & \multicolumn{3}{c}{ Total } & $P$ \\
\cline { 2 - 7 } & berat & $\%$ & $\begin{array}{l}\text { Ring } \\
\text { an }\end{array}$ & $\%$ & $\sum$ & $\%$ & 0,019 \\
\hline Kurang baik & 25 & 59,5 & 4 & 9,5 & 29 & 69,0 \\
\hline Baik & 6 & 14,3 & 7 & 16,7 & 13 & 31,0 & \\
\hline
\end{tabular}

Sumber: Data Primer, 2013

Berdasarkan Tabel 10, maka diketahui bahwa dari total 29 responden $(69,0 \%)$ memiliki pola makan kurang baik, 25 responden $(59,5 \%)$ diantaranya menderita typhoid berat dan 4 responden lainnya $(9,5 \%)$ menderita typhoid ringan. Sedangkan dari total 13 responden $(31,0 \%)$ yang memiliki pola makan baik, 6 responden $(14,3 \%)$ diantaranya menderita typhoid berat dan 7 responden $(16,7 \%)$ menderita typhoid ringan.

Hasil uji statistik Fisher's Exact Test antara variabel pola makan dengan kejadian typhoid $p=0,019$ yang artinya ada hubungan yang signifikan antara pola makan dengan kejadian typhoid.

\section{Hubungan personal hygiene dengan kejadian typhoid}

Tabel 11 Hubungan personal hygiene dengan kejadian typhoid di BLUD RSU Tenriawaru Kab. Bone

\begin{tabular}{llllllll}
\hline \multirow{2}{*}{ Personal hygiene } & \multicolumn{3}{l}{ Kejadian typhoid } & \multicolumn{3}{c}{ Total } & $p$ \\
\cline { 2 - 7 } & Berat & Ringan & $\%$ & $\sum$ & $\%$ & 0,020 \\
\hline
\end{tabular}




\begin{tabular}{lllllll}
\hline Kurang & 28 & 66,7 & 6 & 14,3 & 34 & 81,0 \\
\hline Baik & 3 & 7,1 & 5 & 11,9 & 8 & 19,0 \\
\hline Sumber: Data Primer, 2013 & & &
\end{tabular}

Berdasarkan Tabel 11, maka diketahui bahwa dari total 34 responden $(81,0 \%)$ memiliki personal hygiene yang kurang, 28 responden $(66,7 \%)$ diantaranya menderita typhoid berat dan 6 responden lainnya $(14,3 \%)$ menderita typhoid ringan. Sedangkan yang memiliki personal hygiene yang baik secara keseluruhan berjumlah 8 responden $(19,0 \%), 3$ responden $(7,1 \%)$ diantaranya menderita typhoid berat dan 5 responden $(11,9 \%)$ menderita typhoid ringan.

Hasil uji statistik Fisher's Exact Test antara variabel personal hygiene dengan kejadian typhoid diperoleh $p=0,020$ yang artinya ada hubungan yang signifikan antara personal hygiene dengan kejadian typhoid.

\section{Analisa Bivariat}

\section{Hubungan sanitasi lingkungan dengan kejadian typhoid}

Tabel 12 Hubungan sanitasi lingkungan dengan kejadian typhoiddi BLUD RSU Tenriawaru Kab. Bone

\begin{tabular}{llllllll}
\hline \multirow{2}{*}{$\begin{array}{l}\text { Sanitasi } \\
\text { lingkungan }\end{array}$} & \multicolumn{2}{l}{ Kejadian typhoid } & \multicolumn{3}{c}{ Total } & $P$ \\
\cline { 2 - 8 } 0 & berat & $\%$ & ringan & $\%$ & $\sum$ & $\%$ & 02 \\
\hline Kurang baik & 26 & 61,9 & 5 & 11,9 & 31 & 73,8 & 1 \\
\hline Baik & 5 & 11,9 & 6 & 14,3 & 11 & 26,2 & \\
\hline
\end{tabular}

Sumber: Data Primer, 2013

Berdasarkan Tabel 12, maka diketahui bahwa dari total 31 responden $(73,8 \%)$ memiliki sanitasi lingkungan yang kurang baik, 26 responden $(61,9 \%)$ diantaranya menderita typhoid berat dan 5 responden lainnya $(11,9 \%)$ menderita typhoid ringan. Sedangkan dari total 11 responden $(26,2 \%)$ yang memiliki sanitasi lingkungan yang baik, 5 responden $(11,9 \%)$ diantaranya menderita typhoid berat dan 6 responden $(14,3 \%)$ menderita typhoid ringan.

Hasil uji statistik fisher exact test antara variabel sanitasi lingkungan dengan kejadian typhoid diperoleh $p=0,021$ yang artinya ada hubungan yang signifikan antara sanitasi lingkungan dengan kejadian typhoid.

Hubungan antara pola makan dengan kejadian typhoid

Tabel 13 Hubungan pola makan dengan kejadian typhoid di BLUD RSU Tenriawaru Kab.Bone

\begin{tabular}{|c|c|c|c|c|c|c|c|}
\hline \multirow{2}{*}{ Pola makan } & \multicolumn{4}{|c|}{ Kejadian typhoid } & \multicolumn{2}{|c|}{ Total } & $P$ \\
\hline & berat & $\%$ & Ringan & $\%$ & $\sum$ & $\%$ & \multirow{3}{*}{0,019} \\
\hline Kurang baik & 25 & 59,5 & 4 & 9,5 & 29 & 69,0 & \\
\hline Baik & 6 & 14,3 & 7 & 16,7 & 13 & 31,0 & \\
\hline
\end{tabular}

Sumber: Data Primer, 2013

Berdasarkan Tabel 13, maka diketahui bahwa dari total 29 responden $(69,0 \%)$ memiliki pola makan kurang baik, 25 responden $(59,5 \%)$ diantaranya menderita typhoid berat dan 4 responden lainnya $(9,5 \%)$ menderita typhoid ringan. Sedangkan dari total 13 responden $(31,0 \%)$ yang memiliki pola makan baik, 6 responden $(14,3 \%)$ diantaranya menderita typhoid berat dan 7 responden $(16,7 \%)$ menderita typhoid ringan

Hasil uji statistik Fisher's Exact Test antara variabel pola makan dengan kejadian typhoid $p=0,019$ yang artinya ada hubungan yang signifikan antara pola makan dengan kejadian typhoid.

\section{Hubungan personal hygiene dengan kejadian typhoid}

Tabel 14 Hubungan personal hygiene dengan kejadian typhoid di BLUD RSU Tenriawaru Kab. Bone 


\begin{tabular}{|c|c|c|c|c|c|c|c|}
\hline \multirow{2}{*}{ Personal hygiene } & \multicolumn{4}{|c|}{ Kejadian typhoid } & \multicolumn{2}{|c|}{ Total } & $p$ \\
\hline & Berat & $\%$ & Ringan & $\%$ & $\sum$ & $\%$ & \multirow{3}{*}{0,020} \\
\hline Kurang & 28 & 66,7 & 6 & 14,3 & 34 & 81,0 & \\
\hline Baik & 3 & 7,1 & 5 & 11,9 & 8 & 19,0 & \\
\hline
\end{tabular}

Sumber: Data Primer, 2013

Berdasarkan Tabel 14, maka diketahui bahwa dari total 34 responden $(81,0 \%)$ memiliki personal hygiene yang kurang, 28 responden $(66,7 \%)$ diantaranya menderita typhoid berat dan 6 responden lainnya $(14,3 \%)$ menderita typhoid ringan. Sedangkan yang memiliki personal hygiene yang baik secara keseluruhan berjumlah 8 responden $(19,0 \%), 3$ responden $(7,1 \%)$ diantaranya menderita typhoid berat dan 5 responden $(11,9 \%)$ menderita typhoid ringan.

Hasil uji statistik Fisher's Exact Test antara variabel personal hygiene dengan kejadian typhoid diperoleh $p=0,020$ yang artinya ada hubungan yang signifikan antara personal hygiene dengan kejadian typhoid.

\section{PEMBAHASAN}

\section{Hubungan sanitasi lingkungan dengan kejadian typhoid}

Dengan membandingkan teori dan penelitian yang ada, dapat dikemukakan bahwa dari hasil penelitian dengan melihat analisis bivariat yang telah dijelaskan bahwa tidak dapat memberikan jaminan bahwa yang memiliki sanitasi lingkungan yang baik, tidak menderita penyakit typhoid. Hasil analisis bivariat secara kuantitatif menunjukkan bahwa terdapat hubungan antara sanitasi lingkungan dengan kejadian typhoid. Hal ini terlihat dari nilai kemaknaan yang dihasilkan dari hasil uji fisher's exact test yaitu $p=0,021$, maka hipotesis alternatif dalam penelitian ini mengasumsikan bahwa ada hubungan antara sanitasi lingkungan dengan kejadian typhoid di BLUD RSU Tenriawaru Kabupaten Bone.

Sanitasi lingkungan yang buruk memiliki demam typhoid yang berat karena hal ini terdiri dari sumber air bersih yang tercemar, kondisi lingkungan sekitar rumah maupun di dalam rumah yang tidak bersih (sampah berserakan di mana-mana), kotoran hewan di jalanan umum yang tidak dibersihkan. Menurut pendapat (Ridwan, 2012). Sanitasi merupakan upaya kesehatan masyarakat yang menitik beratkan pada pengawasan terhadap berbagai pada faktor yang mempengaruhi atau yang mungkin mempengaruhi derajat kesehatan manusia. Seperti Lebih mendahulukan usaha pencegahan terhadap berbagai faktor lingkungan sedemikian rupa. Penelitian yang sama, pada beberapa tahun sebelum melaporkan kasus bahwa Dengan Sanitasi lingkungan yang buruk berdampak meningkatkan kejadian typhoid.

Menurut Feriel yang dikutip oleh (Irianto Kus and Waluyo K, 2010; L and Andarmoyo S, 2012) Pola hidup bersih dan sehat adalah sebagai hidup di lingkungan yang memenuhi standar kebersihan dan kesehatan serta menerapkan pola atau perilaku hidup bersih dan sehat. Lingkungan yang sehat dapat memberikan dampak terhadap kualitas kesehatan. Kesehatan seseorang akan menjadi lebih baik apabila lingkungan yang ada di sekitarnya sehat. Begitu juga sebaliknya, kesehatan seseorang akan menjadi buruk apabila lingkungan yang ada di sekitarnya kurang sehat atau baik. Sehingga sanitasi lingkungan terjaga dengan baik maka akan menurunkan angka kejadian typhoid sebaliknya sanitasi lingkungan tidak terjaga dengan baik maka menambah angka kejadian typhoid.

Hasil penelitian menunjukkan dominan responden memiliki sanitasi lingkungan yang kurang. Hal ini sejalan penelitian Rotua S.S (2008) yang menyatakan sebagian besar responden dari masyarakat yang menjadi subjek penelitian (penyakit typhoid) memang memiliki sanitasi lingkungan yang kurang sehat antara lain sumber air bersih yang tercemar, kondisi lingkungan sekitar rumah maupun di dalam rumah yang tidak bersih,

Berdasarkan hasil penelitian dan pendapat yang telah dikemukakan, maka dikatakan bahwa pada hasil penelitian ini sejalan dengan pendapat yang dikemukakan. Sanitasi lingkungan yang kurang baik, berdampak pada kejadian typhoid.

\section{Hubungan pola makan dengan kejadian typhoid}

Dengan membandingkan teori dengan penelitian yang ada, maka dapat dikemukakan bahwa dari hasil penelitian dengan melihat analisis bivariat yang telah dijelaskan bahwa tidak dapat memberikan jaminan bahwa yang memiliki pola makan yang baik, tidak mengalami penyakit typhoid berat. Hasil analisis bivariat secara kuantitatif menunjukkan bahwa terdapat hubungan antara pola makan dengan kejadian typhoid. Hal ini terlihat dari nilai kemaknaan yang dihasilkan dari hasil uji fisher's exact test 
yaitu $p=0,019$, maka hipotesis alternatif dalam penelitian ini menyimpulkan bahwa terdapat hubungan antara pola makan dengan kejadian typhoid di RSUD Tenriawaru Kabupaten Bone.

Penelitian yang dilakukan oleh Heru Laksono (2009) dengan desain case control, mengatakan bahwa kebiasaan jajan di luar mempunyai resiko terkena penyakit demam typhoid 3,6 kali lebih tinggi dibandingkan dengan kebiasaan tidak jajan diluar $(\mathrm{OR}=3,65)$ dan seseorang yang tidak menjaga kebersihan makanan yang dimakan maka beresiko terkena penyakit demam typhoid 2,7 lebih tinggi dibandingkan dengan yang menjaga kebersihan makanan yang dikomsumsinya $(\mathrm{OR}=2,7)$.menurut pendapat (Safitri Astri, 2012). Pada dasarnya tingkat kesehatan seseorang di pengaruhi oleh konsumsi dan gaya hidupnya. Akibat dari keterbatasan waktu untuk mempersiakan menu makanan yang sehat ataupun adanya kebutuhan tambahan zat gizi tertentu. Akhirnya cenderung memilih makanan yang siap saji.

Menurut (Irianto Kus and Waluyo K, 2010) menyebutkan bahwa pola hidup sehat yaitu dengan pola atau gaya hidup yang lebih berfokus pada hal-hal kesehatan, terutama makanan oleh karena itu, Harus selalu menjaga kebersihan makanan yang dikomsumsi karena penyebaran kuman salmonella thypi melalui makanan dan minuman yang terkontaminasi kemudian masuk kedalam tubuh manusia akhirnya mengakibatkan penyakit typhoid.

Hasil penelitian dan pendapat yang telah dikemukakan, dapat dikatakan bahwa pada hasil penelitian ini seiring dengan pendapat yang dikemukakan bahwa pola makan yang buruk maka akan berdampak pada typhoid berat yang diderita

\section{Hubungan personal hygiene dengan kejafian typhoid}

Berdasarkan pada hasil penelitian terkait hubungan personal hygiene dengan kejadian typhoid di RSUD Tenriawaru Kabupaten Bone. Responden yang memiliki personal hygiene yang baik tidak dapat memberikan jaminan tidak menderita penyakit typhoid berat.ini ditunjukkan dari hasil analisis bivariat secara kuantitatif menunjukkan bahwa terdapat hubungan antara personal hygiene dengan kejadian typhoid. Hal ini terlihat dari nilai kemaknaan yang dihasilkan dari hasil uji fisher's exact test yaitu $p=0,020$, maka hipotesis alternatif dalam penelitian ini mengasumsikan bahwa terdapat hubungan antara personal hygiene dengan kejadian typhoid di RSUD Tenriawaru Kabupaten Bone.

Berdasarkan hasil penelitian Lubis, R. di RSUD. Dr. Soetomo (2000) dengan desain case control, mengemukakan bahwa hygiene seseorang yang kurang, memiliki resiko terkena penyakit demam typhoid 20,8 kali lebih tinggi dibandingkan dengan yang hygiene seseorang yang baik $(\mathrm{OR}=20,8)$ dan kualitas air minum yang tercemar berat coliform beresiko 6,4 kali lebih tinggi terjangkit penyakit demam typhoid dibandingkan dengan yang kualitas air minumnya tidak tercemar berat coliform $(\mathrm{OR}=6,4)$. Menurut (Land Andarmoyo S, 2012) anak yang mempunyai kebiasaan buruk seperti tidak mencuci tangan sebelum makan maka beresiko terkena penyakit demam typhoid 2,7 lebih tinggi dibandingkan dengan kebiasaan mencuci tangan sebelum makan $(\mathrm{OR}=2,7)$.

Menurut Depkes RI, 2004, Hygiene merupakan upaya kesehatan dengan cara memelihara dan menjaga kebersihan subyeknya seperti mencuci tangan dengan air bersih yang mengalir memakai sabun untuk melindungi kebersihan tangan, mencuci piring untuk melindungi kebersihan alat makan, membuang bagian makanan yang rusak untuk melindungi keutuhan kebersihan makanan secara keseluruhan

Menurut (Irianto Kus and Waluyo K, 2010) Kebersihan perorangan adalah cara perawatan diri sendiri untuk menjaga kesehatan. Kebersihan perorangan paling utama untuk diperhatikan. Pemeliharaan kebersihan perorangan dibutuhkan untuk kenyamanan perorangan dalam keamanan dan kesehatan. Dalam kehidupan sehari-hari kebersihan adalah hal yang paling utama dan wajib diperhatikan karena kebersihan dapat mempengaruhi kesehatan dan psikis seseorang. Kebersihan itu sangat dipengaruhi oleh nilai perorangan dan kebiasaan. Hal-hal yang sangat berpengaruhi diantaranya kebudayaan, sosial, keluarga, pendidikan, persepsi seseorang terhadap kesehatan, serta tingkat perkembangan.

Berdasarkan hasil penelitian dan pendapat yang telah diuraikan, maka dapat dikatakan bahwa pada hasil penelitian ini sejalan dengan pendapat yang telah diuraikan. Seseorang dengan personal hygiene yang kurang baik maka berisiko terinfeksi penyakit typhoid berat. 


\section{KESIMPULAN DAN SARAN \\ KESIMPULAN}

Berdasarkan hasil penelitian tentang hubungan sanitasi lingkungan, pola makan dan personal hygiene dengan kejadian typhoid di BLUD RSU Tenriawaru Kabupaten Bone tahun 2013, dapat disimpulkan bahwa ada hubungan yang bermakna antara sanitasi lingkungan dengan kejadian typhoid, Ada hubungan yang bermakna antara pola makan dengan kejadian typhoid, Ada hubungan yang bermakna antara personal hygiene dengan kejadian typhoid di BLUD RSU Tenriawaru Kabupaten Bone.

\section{SARAN}

Diharapkan pasien yang menderita penyakit typhoid, tidak merasa terbebani, cemas berlebihan dengan berat ringannya penyakit typhoid yang diderita, harus mematuhi anjuran dokter supaya mempercepat proses penyembuhan penyakit typhoid yang diderita.

\section{KEPUSTAKAAN}

Ardiansyah Muhammad (2012) medikal Bedah. Jogjakarta: DIVA Press.

Hariwijaya and Djaelani (2011) Panduan Menyusun Skripsi dan Tesis. Yogyakarta: Siklus.

Harjo (2010) 'Demam Thypoid'.

Irianto Kus and Waluyo K (2010) Gizi dan Pola Hidup Sehat. Bandung: Yrama Widya.

L, I. and Andarmoyo S (2012) Personal Hygiene. Yogyakarta: Graha Ilmu.

Ridwan (2012) 'Memahami Arti Sanitasi Lingkungan Untuk Menjaga Kebersihan dan Kesehatan', kesehatan.

Safitri Astri (2012) Deteksi Dini Gejala Pencegahan pengobatan Asam Urat. Yogyakarta: Pinang Merah.

saidam Gouzali (2011) memahami berbagai penyakit. Bandung: Alfabeta. 